\title{
河川流量の頻度解析における適合度と安定性の評価

\author{
GOODNESS-OF-FIT AND STABILITY ASSESSMENT \\ IN FLOOD FREQUENCY ANALYSIS
}

\author{
田中茂信 1 ・宝 馨 ${ }^{2}$ \\ Shigenobu TANAKA and Kaoru TAKARA \\ ${ }^{1}$ 正会員 工修 (財) 国土開発技術研究センター 調査第一部（广 105-0001 港区虎ノ門 2-8-10） \\ 2 正会員 工博 京都大学防災研究所教授 水災害研究部門（广 611-0011 宇治市五ヶ庄）
}

\begin{abstract}
This paper describes the results obtained from flood frequency analysis in river basins in Japan. Using annual maximum discharge data at ninety-nine locations on the major rivers, the authors fitted a number of frequency analysis models (probability distributions) and evaluated them in terms of not only goodness of fit and but also stability of quantile estimates. The standard least-square criterion (SLSC) is used as a goodness-of-fit criterion. The stability of quantile estimates is assessed in terms of estimation error obtained by the jackknife method, which can be used for bias correction and quantification of estimation error. Based on the application results for ninety-nine samples, this paper has revealed: (1) goodness of fit of various models; (2) that SLSC $=0.04$ could be a threshold for good-fitted models; and (3) that the jackknife estimation error can be an index to evaluate the stability of the models. Importance of graphical analysis using probability paper is stressed.
\end{abstract}

Key Words : River discharge, Goodness-of-fit criterion, Stability of quantile estimates, The jackknife

\section{1.はじめに}

1997年に河川法が改正された. 従来, 河川の工事 は工事実施基本計画に基づいて行われてきたが, 河 川法改正により, 河川整備の基本となるべき方針に 関する事項（河川整備基本方針）と具体的な河川整 備に関する事項(河川整備計画)の 2 段階に区分し, 後者については地方公共団体の長, 地域住民等の意 見を反映する手続きが導入された.これらの段階に おいて, 計画決定過程の透明化, 情報公開, 説明責 任などが必然的に要求される.したがって, 河川整 備基本方針に定められる基本高水や計画高水流量の 決定の際に用いたデー夕, 手法, 判断の根拠などに ついても明らかにしておく必要があり, 客観的かつ 科学的合理的なデー夕および手法が要求される.

計画の基本量である外力を定める際に水文頻度解 析が用いられるが, この過程においても曖昧さや主 観的判断を極力排除し, 判断の基準を明確にする必 要がある.

従来, 高水計画の検討にあたっては, 十分な大き さの流量資料および時間雨量が得られなかったこと
もあって, 日雨量をベースとした検討手法が主に用 いられてきた. 近年, 一級水系の主要な地点では概 ね 40 年間前後の流量観測資料が蓄積されてきてい る. その洪水流量のピーク值を直接頻度解析し, 再 現期間 100 年ないし 150 年, 200 年の確率流量を求 め, それを河川整備の基本量とする考え方もある. 本研究では, 全国の多数の河川流域における極值 流量データベースを構築し, 統一的な手法で頻度解 析を行った. 特に, 慣用されている多くの確率分布 について, 客観的な規準を用いて適合度と安定性を 評価した結果を報告する.

\section{2. 研究方法}

従来, 河川計画においては, 確率水文量の推定に あたって用いる確率分布の選択は, 最小二乗法や上. 位 10 点最小二乗法, 確率紙へのプロットの視覚的 判断などが用いられてきた. しかしながら,これら は, 主観的判断によるものであったり, 確率分布を ぞれかに決定した後に最適化を行うものであるな ぞ, 適合度の客観的判断に疑問が残る. 宝らは適合 


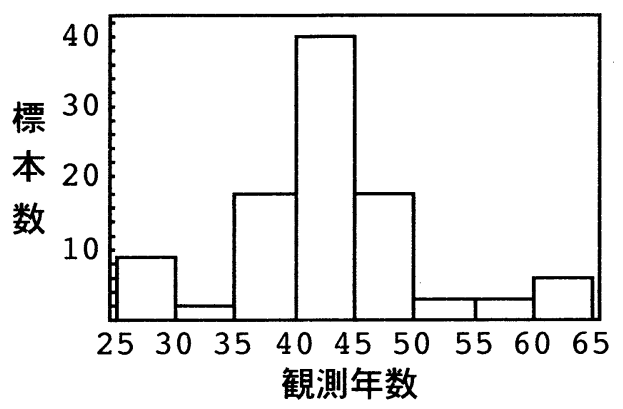

図 -1 年最大值標本の観測年数

度の絶対的な判定基準として標準最小二乗規準 (SLSC)を提案している ${ }^{1)}$. 適合度の判定規準には, 他に相関係数や最大対数尤度, Akaike の情報量規 準などがある.最大対数尤度と Akaike の情報量規 準は, 比較対象の確率分布の中での相対的評価しか できない. 相関係数よりSLSCの方が規準の持つ意 味が明確である.このようなことを踏まえ, 本研究 では，SLSCにより適合度の評価を行った。

また，一般に，母数の個数が多くなるにつれて標 本によく適合するようになるため, 適合度の観点か らは母数の個数が多い確率分布の方が適合している と判断されることが多い. しかしながら，このよう な確率分布は, 新しくデータが加わった際に, 非超 過確率の大きい部分の確率水文量の変動が大きくな る可能性がある.流域の長期的な管理の目標の基礎 となるものがデータの追加によってあまり変動する のも困るし，そもそもその確率水文量に対する信頼 が摇らいでしまう.このため, 単に適合度がよい確 率分布ではなく, データの追加に対しても安定的な 確率分布を選択する必要がある. 本研究では, リサ ンプリング手法を用いて安定性の評価を行った.

解析手順は, まず, 従来水文統計の分野で用いら れてきた分布モデルや極值統計の分野で用いられて (る確率分布の中から, 宝・高棹 ${ }^{2}$, 星 ${ }^{3)}$ が示してい る各分布と標本サイズに対して最適な母数推定法を 用いて標本の母数べクトルを求める. 用いた分布モ デルは, 指数分布【Exp】(Lモーメント法), グン ベル分布 (Lモーメント法), 平方根指数型最大值分 布 ${ }^{4)}$ [SQRT-ET】(最尤法), 一般極值分布【GEV】 (Lモーメント法), 対数ピアソンIII型分布 (原標本 の積率解【LP3Rs】, 対数標本の積率解 【LP3Ls】), 対数正規分布 (3母数の場合岩井法, 2 母数の場合 最尤法【LN2】）である. 次に, SLSCにより, 確率 分布の適合度を評価する. 最後に, 適合度が一定の 基準を満足するものについて, リサンプリング手法 である jackknife 法を用いて安定性の評価を行う.

\section{3. 解析結果}

（1）解析に用いた資料
今回, 解析に用いた資料はわが国の68の一級水系 における 99 箇所の流量である. 観測流量は観測地 点より上流の氾濫やダムなどによる貯留の影響を受 けている.この影響を流出解析により取り除いた流 量を解析の対象にした. 流量の観測が始まった時期 が異なるため, 年最大值で整理されている 99 標本 の観測年数は図-1のような度数分布となる. 40 年 〜 44 年が 40 標本, 35 年〜 39 年と 45 年〜 49 年が 18 標本であり, 平均值は 42.1 年である.

\section{(2)確率分布の適合度}

\section{a)SLSC の算定}

SLSC は確率分布の理論クオンタイル（非超過確 率 $\mathrm{p}$ または確率年Tに対応する変量の值）と標本順 序統計量との誤差の度合を標準変量を物差しとして 測る指標で次式(1), (2)で定義される ${ }^{1)}$.

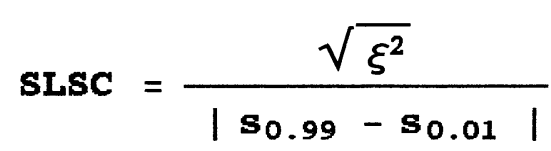

$$
\xi^{2}=\frac{1}{N} \sum_{i=1}^{N}\left(s_{i}-s_{i}{ }^{*}\right)^{2}
$$

ここに, $\mathrm{S}_{0.99}, \mathrm{~S}_{0.01}$ : それぞれ非超過確率 0.99 と 0.01 に対する当該確率分布の標準変量, $\mathrm{N}$ : 標本の 大きさ, $\mathrm{s}_{\mathrm{i}}$ : 順序統計量を推定母数で変換した標準 変量, $\mathrm{S}_{1}{ }^{*}$ : プロッティングポジション ${ }^{5)}$ に対応した 理論クオンタイルを推定母数によって変換した標準 変量である.

確率分布によっては標準変量の考方方がいくつも あり得るものがある. 本研究では, 平方根指数型最 大值分布と一般極值分布の $\mathrm{s}_{\mathrm{i}}{ }^{*}$ はグンベル分布の $\mathrm{s}_{i}{ }^{*}$ と同じものを用いた.

また，SLSCの算定にあたっては，各種の分布に 対して近似的に不偏なクォンタイルを与える Cunnane の公式をプロッティングポジションに用 いた ${ }^{6}$.

\section{b)確率分布のSLSC}

図-2に各確率分布毎に 99の標本に対して求めた SLSCのヒストグラムを示す.なお, SLSCが 0.07 以上の階級には母数推定がうまく行かなかった場合 や対数正規分布で対数変換標本值の歪夕係数の絶対 值が 0.3 を越えた場合（この場合は対数正規分布を あてはめるのは不適切である可能性が高い3) を含 めて表示している.

SLSCが小さいものが多いのは, LP3Ls 分布, 岩 井法, GEV 分布である.これらはすべて 3 母数の 確率分布モデルである. LP3Rs分布も 3 母数である 

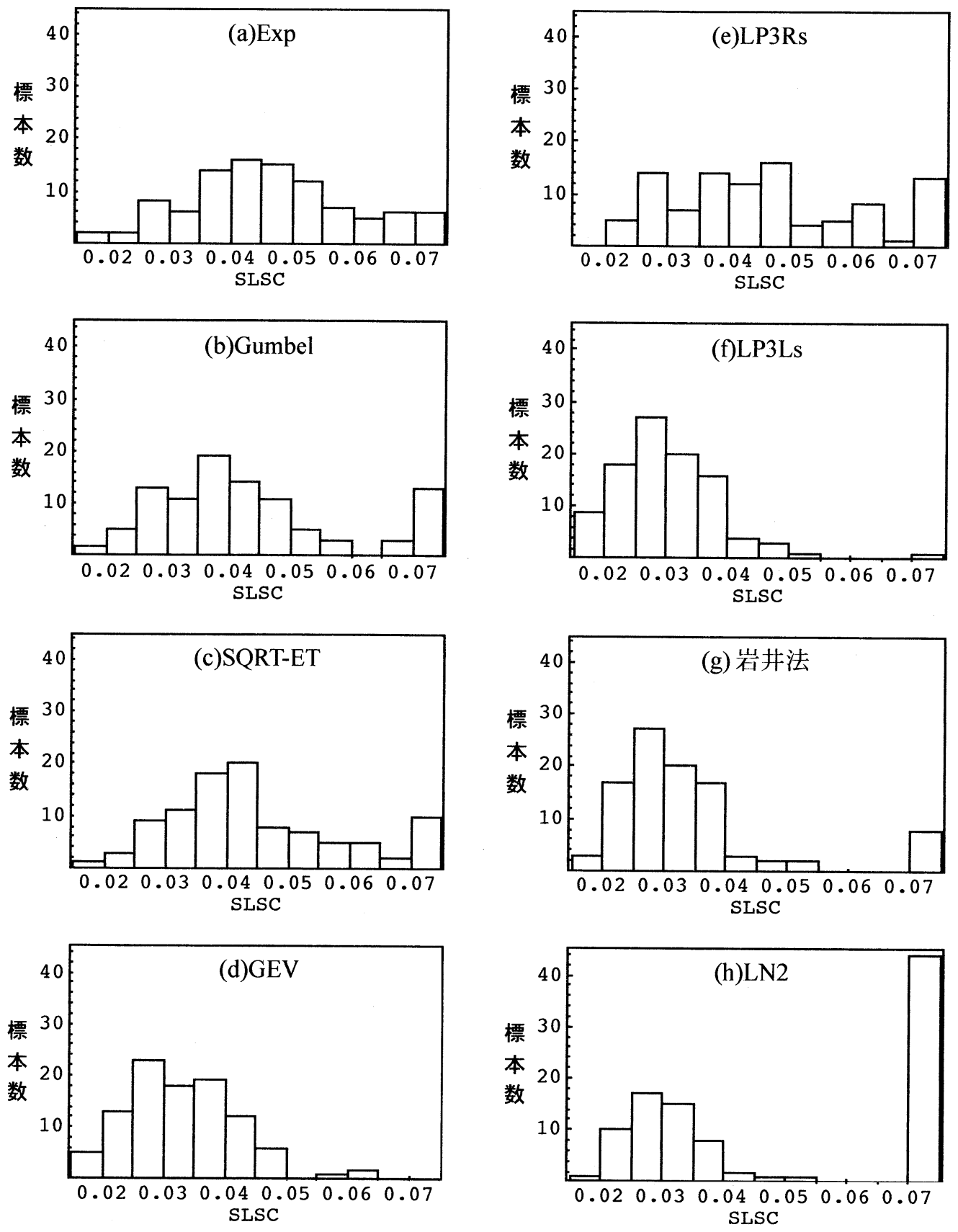

図-2 各確率分布モデル毎に 99 箇所の標本に対して求めたSLSC のヒストグラム

がSLSCが小さいものはそれほど多くはない。一 方, 2 母数の分布は, 一般的に 3 母数の分布より SLSCが小さいものが少なく, LN2 分布のつぎにグ ンベル分布がSLSCが小さいものが多い. なお, 図一 2(h)にみられるように全標本の $44 \%$ で対数変換後の 歪み係数の絶対值が 0.3 を越えている.

図-3 は各標本に対してSLSC が最小になった確 率分布を示したものである. LP3Ls 分布が53\%を 占め, つぎに GEV 分布, 岩井法がつづく. LP3Rs 分布とLN2 分布は, 今回対象とした標本ではSLSC が最小になることがなかった。

図 -4 はある標本に対して 8 つの確率分布のうち のSLSCの最小值をとってヒストグラムで示したも のである. SLSC=0.02以下が $15 \%, 0.03$ 以下が 67
\%，0.04以下が 96\%となっている．宝・高棹は， $\mathrm{SLSC}=0.02$ を十分な適合度と判断される基準, $\mathrm{SLSC}=0.03$ を満足すべき適合度の判定基準として いる11. しかしながら，今回対象とした流量資料で は, 満足すべき適合度の判定基準として $\mathrm{SLSC}=0.03$ をとると, 3 分の 1 の標本は適合度を 満足する確率分布モデルが 1 つもない状況になる. 本来, 適合度の評価は適合度の悪いモデルをふるい 分けるものであり, 結果としてどのモデルも残らな いという状況になる判定基準は適当ではない。 ま た，河川流量は，一般に水位を測定して流量に換算 しているが, 観測所によっては, 低水路満杯流量付 近の流量が少なかったり, 河川横断面形状の急変部 付近の流量データが確率紙上で階段状にプロットさ 


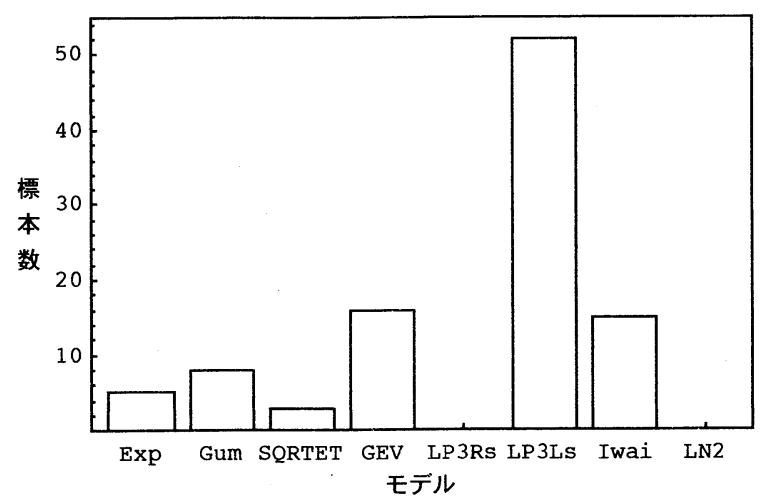

図-3 SLSCが最小になった確率分布モデルの頻度

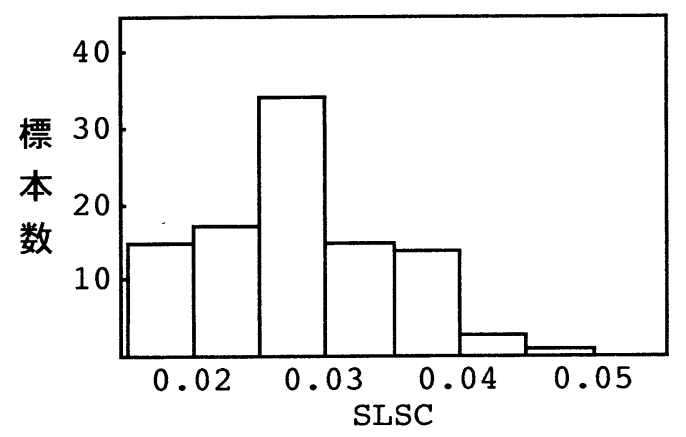

図 -4 SLSC 最小値の頻度分布

れたりすることがある. 図-5にその一例を示す.プ ロットの全体的な傾向はモデルでも捉えられている が, 階段状にプロットされている部分はモデルとの 乘離が大きくなる状況にあり，これがSLSCの值を 大きくしている一因になっている.この図において 流量が $1,700 \mathrm{~m}^{3} / \mathrm{s}$ 付近に観測值が見られないが, こ の流量がこの観測所における低水路満杯流量となっ ており, 水位流量曲線の特性が変わる部分に相当し ている，一方，図 -1 に示したように観測期間が平 均的に 42 年程度であることから, 超過確率 $1 / 100$ 〜 1/200 の確率水文量は外挿により求めることに なり, なんらかのモデルを必要とする. このような 状況を踏まえ, 河川流量の適合度の判定基準を $\mathrm{SLSC}=0.04$ 程度に設定することが適当と考えられ る.

\section{(3)安定性評価}

安定性の評価はリサンプリング手法で行う。リサ ンプリング手法にはjackknife 法や bootstrap 法が ある7). jackknife法は大きさN個の標本のうち任意 の 1 データを欠いたデー夕数 $\mathrm{N}-1$ 個の標本を $\mathrm{N}$ セット作成し,これらの標本から求めた統計量をも とに不偏推定值およびそのまわりの推定誤差を算定 する手法である. 一方, bootstrap 法は大きさ $\mathrm{N}$ 個 の標本から重複を許して任意にN個取り出した標本 を複数作成し,これらの標本から求めた統計量をも とに不偏推定值およびそのまわりの推定誤差を算定 する手法である. jackknife法は計算回数が少なく,

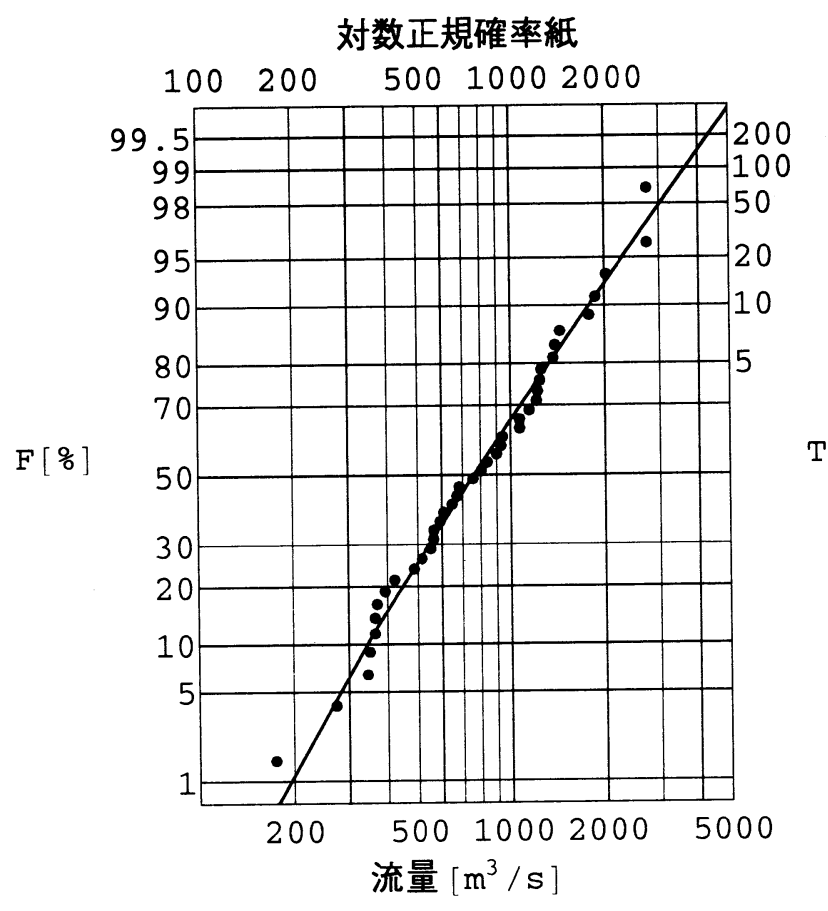

図 -5 E川の年最大流量のプロットと 岩井法によるあてはめ

作成する標本数および不偏推定値, 推定誤差が一意 的に定まるのに対し, bootstrap法は作成する標本 数が任意に設定でき, 作成する標本数によって不偏 推定值や推定誤差が異なる. このため, 今回の検討 における確率分布モデル相互の安定性評価の指標と してはjackknife 法を用いた.

jackknife 法による偏りを補正した推定值は,

$$
\bar{\psi}=\mathbf{N} \hat{\psi}-(\mathbf{N}-1) \hat{\psi}_{(.)}
$$

推定誤差分散は,

$$
\mathbf{s}^{2}=\frac{(\mathbf{N}-1)}{\mathbf{N}} \sum_{i=1}^{N}\left(\psi_{(i)}-\hat{\psi}_{(\cdot)}\right)^{2}
$$

で求められる.ここに, $\hat{\psi} は N$ 個のデー夕を全て 用いたときの統計量, $\boldsymbol{\Psi}_{(\mathrm{i})}$ は i 番目のデー夕を除 いた $N-1$ 個のデータを用いた統計量であり, $\hat{\psi}_{(.)}$はその平均値

$$
\hat{\psi}_{(\cdot)}=\frac{1}{N} \sum_{i=1}^{N} \psi_{(i)}
$$

である. 本研究では確率水文量の安定性を評価す るためひに確率水文量をとり, (4)式の平方根で表さ れる推定誤差 $\mathrm{s}$ を安定性の評価指標として用いた.

図-6 はA川の年最大値について LP3Rs 分布と 
LP3Ls分布をあてはめるとともに, これらについて jackknife 法を適用して得られたjackknife 推定値 と推定誤差を併せて示したものである.この観測所 においては, 低水路満杯流量が $2,700 \mathrm{~m}^{3} / \mathrm{s}$ であり, この付近の観測資料がなく, 再現期間 10 年以上の 範囲のバラツキが大きめである. しかしながら, SLSC は前者が 0.023 , 後者が 0.022 であり, 比較 的よく適合している部類にはいる. 実線はLP3Rs分 布を示している. そのうち太い実線は全資料を用い た推定曲線である. 3 本の細い実線はjackknife 法 による推定曲線であり, 中央の細線がjackknife 推 定值，その両側の細線が推定誤差の幅を示してい る.この両外側の曲線は観測值をほとんど包絡する ように引かれている. また，中央の線と太い実線を 比較すると, 太い実線がjackknife 推定值（中央の 細線）より少し左に偏っており, 同じ非超過確率に 対し小さめの確率水文量を与えていることがわか る.

一方，破線はLP3Ls分布を示している. 先程と同 様に, 細い破線の両側の線が観測值をほとんど包絡
するように引かれているが, 非超過確率の大きい部 分でその広がりが大きくなっている. jackknife 推 定値と全資料を用いた確率水文量はあまり大きな差 はないが,ほんの少しだけ全資料を用いた確率水文 量が jackknife 推定値を上回っている.

この場合, 再現期間 100 年の確率水文量は, jackknife 法により, LP3Rs 分布が $+160 \mathrm{~m}^{3} / \mathrm{s}$ の修 正, LP3Ls 分布が $-30 \mathrm{~m}^{3} / \mathrm{s}$ の修正となり, お互い が近づく方向に修正されている.

表-1は, A川の年最大值について適合度と安定性 の指標を示したものである. 2 母数対数正規分布は 歪み係数の絶対值が 0.3 を越えたので不適 $(\mathrm{NG})$ と してある. また, 岩井法はjackknife 推定值が負に なっており, 適切に求められない.このような状況 はStedingerのクォンタイル法においてもいくつか の標本でみられることが確認された.このような場 合は, bootstrap 法を適用する必要がある. SLSC でぬると指数分布が適合度を满足しないと判断され る. 結局, 5 つのモデルが残り,・これについて, jackknife 推定誤差から判断すると, グンベル分布

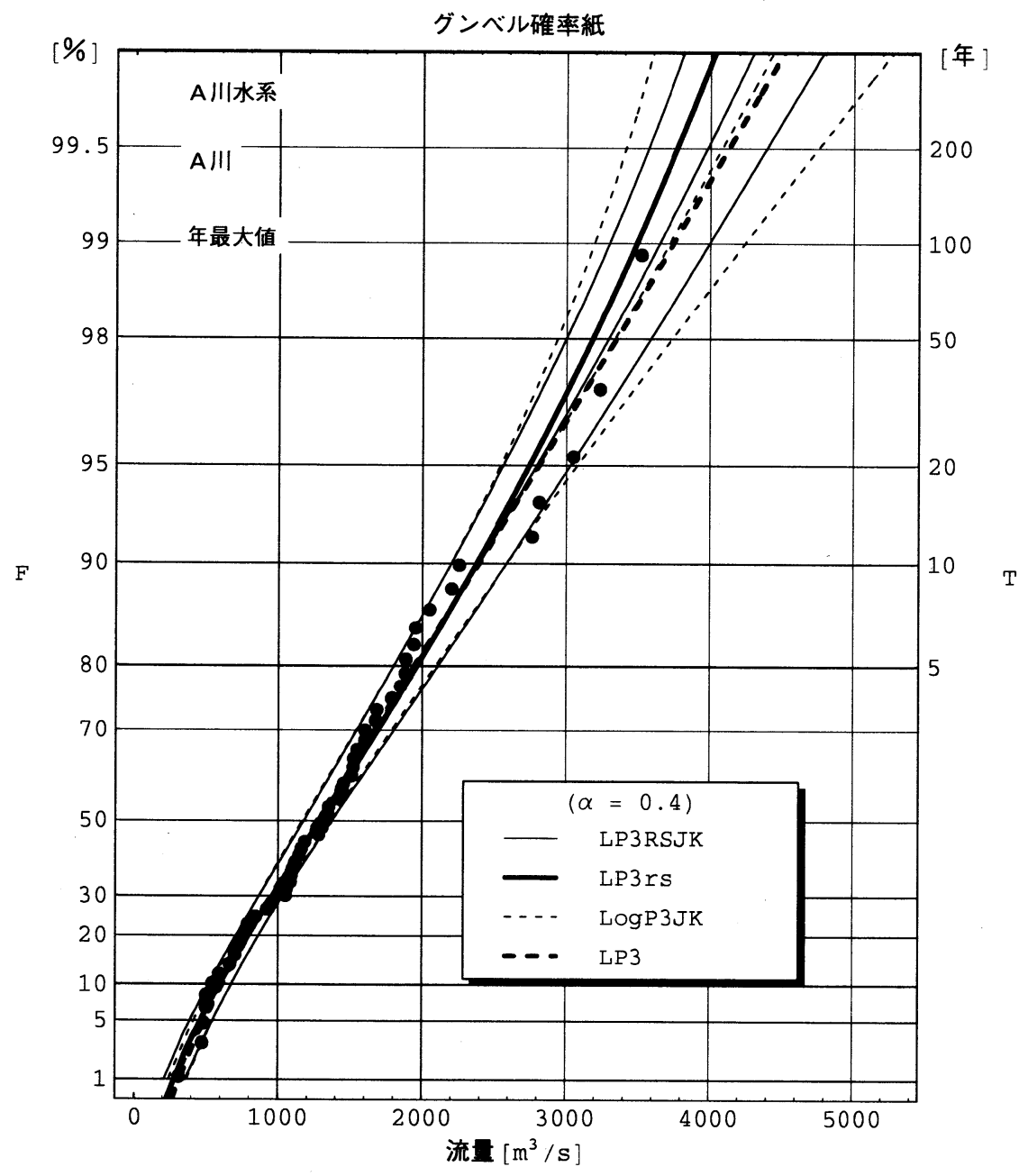

図-6 A川の年最大流量への対数ピアソンIII型分布 (LP3Rs とLP3Ls) のあてはめおよびそれらの jackknife 推定值, 推定誤差 
表-1 A川の適合度と安定性の指標

\begin{tabular}{|c|r|r|r|r|r|r|r|c|}
\hline 確率分布モデル & \multicolumn{1}{|c|}{ 指数 } & グンベル & SQRT-ET & GEV & LP3RS & LP3Ls & 岩井法 & LN2 \\
\hline \hline SLSC & 0.042 & 0.023 & 0.033 & 0.023 & 0.023 & 0.022 & 0.022 & NG \\
\hline Q100全資料 & 4,260 & 3,703 & 4,633 & 3,750 & 3,487 & 3,746 & 3,887 & NG \\
\hline Q100jackknife推定値 & 4,260 & 3,703 & 4,681 & 3,736 & 3,646 & 3,717 & $-3,452$ & NG \\
\hline Q100jackknife推定誤差率 & $9.5 \%$ & $9.2 \%$ & $9.6 \%$ & $14.5 \%$ & $9.5 \%$ & $14.1 \%$ & - & NG \\
\hline Q400jackknife推定誤差率 & $9.9 \%$ & $9.6 \%$ & $10.2 \%$ & $19.6 \%$ & $11.3 \%$ & $18.8 \%$ & - & NG \\
\hline
\end{tabular}

が良さそうである。

図-7はA川の年最大值にグンベル分布をあては めたものである，2母数であるので，推定誤差の幅 が狭く, 非超過確率の大きい部分でもそれほぼ広が ることはない. な拉, jackknife 推定值が全資料を 用いた推定曲線と重なっている.グンベル分布や指 数分布を L モーメント法で母数推定する場合には jackknife 推定值が全資料を用いた推定值と一致す ることが確認できる.したがって，Lモーメント法 で母数推定するグンベル分布や指数分布は不偏推定 值を与えるので適合度が満足されれば優れた分布モ デルである.

このように，リサンプリング手法を用いることに より, 適合度が満足される確率分布モデルの中から 安定性のよいモデルを選ぶことができる. その際, その結果を確率紙に表示して, あてはめたモデルと データの関係を確認しておく必要がある。

\section{4. 結論}

全国68の一級水系における99地点の年最大流量 資料を統一的な手法で確率評価を行った. 適合度と 安定性から評価し，以下のことがわかった。

(1)各確率分布モデルの適合度を明らかにした。

（2）河川流量の満足すべき適合度の基準として $\mathrm{SLSC} \fallingdotseq 0.04$ とするのが適当である.

(3)安定性評価の指標としてjackknife推定誤差が 有力な指標となる.

(4)jackknife 推定值, jackknife 推定誤差を確率 紙にプロットすることにより, 選択する確率分 布モデルの総合的なチェックが可能となる.

謝辞 : 今回の検討にあたって，建設省には貴重な 資料を提供いただいた。ここに記して感謝の意を表 します。

\section{参考文献}

1）宝 馨, 高棹琢馬 : 水文頻度解析における確率分布モ デルの評価規準，土木学会論文集，第 393 号 / II -9, pp.151-160, 1988.

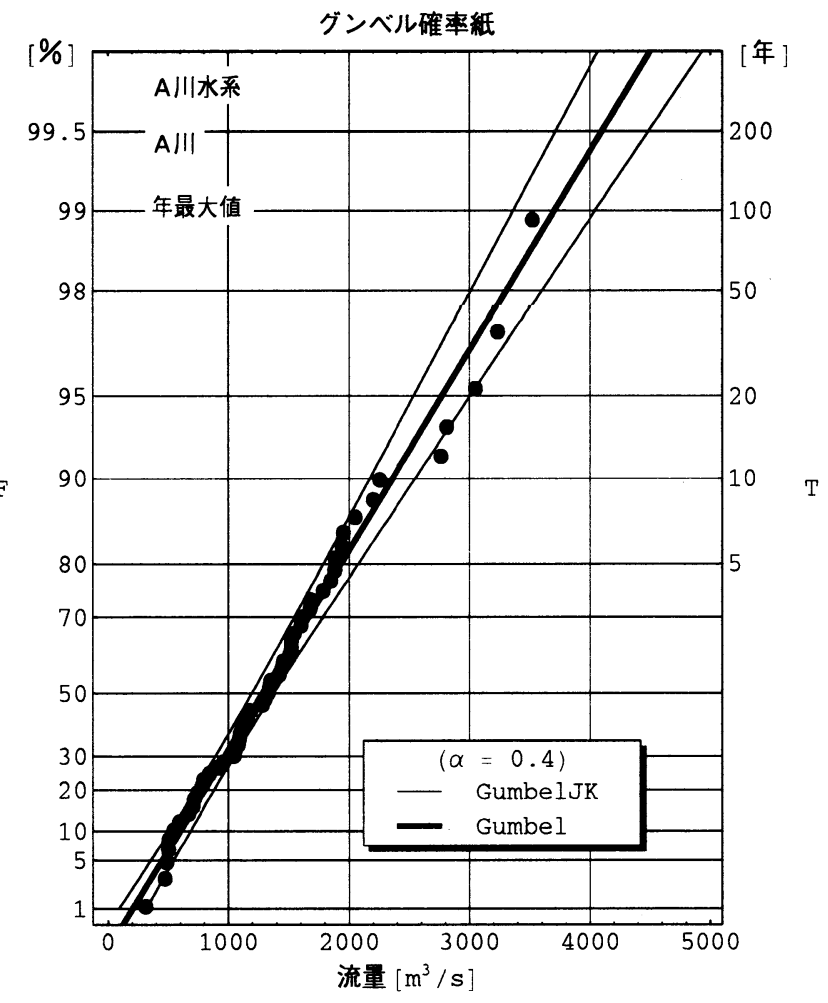

図-7 A川0年最大流量とグンベル分布および その jackknife 推定值, 推定誤差

2) 宝 馨, 高棹琢馬 : 水文頻度解析モデルの母数推定法 の比較評価, 水工学論文集, 士木学会, 第 34 巻, pp.712, 1990.

3) 星 清: 水文統計解析, 開発上木研究所月報, No.540, pp.31-63, 1998.

4) 江藤剛治, 室田 明, 米谷恒春, 木下武雄 : 大雨の頻 度, 土木学会論文集, 第 369 号 / II -5, pp.165-174, 1986.

5）たとえば, 竹内邦良: 水文資料の基本統計処理，水文・ 水資源ハンドブック, 7.2, 水文・水資源学会編, 朝倉 書店, pp.234-237, 1997.

6) Stedinger, J. R., Vogel, R. M. and FoufoulaGeorgiou, E. : Frequency Analysis of Extreme Events, Chap. 18, Handbook of Hydrology, (Ed.) D. R. Maidment, McGraw-Hill, New York, pp.18.118.66, 1993.

7) Efron, B. : The Jackknife, the bootstrap and Other Resampling Plans, SIAM Monograph, No.38, p.92, 1982.

(1998.9.30受付) 